\title{
Erratum to: Assessment of coastal communities' vulnerability to floods using indicator-based approach: a case study of Greater Accra Metropolitan Area, Ghana
}

\author{
Paul William Kojo Yankson ${ }^{1}$ - Alex Barimah Owusu ${ }^{1}$ • \\ George Owusu $^{1} \cdot$ John Boakye-Danquah $^{2} \cdot$ Jacob Doku Tetteh $^{1}$
}

\section{Erratum to: Nat Hazards DOI 10.1007/s11069-017-2985-1}

Due to an oversight during the editorial process, the first author's name was incorrectly given as William Kojo Paul Yankson instead of Paul William Kojo Yankson in the initial online publication of this article. The original article has been corrected.

The online version of the original article can be found under doi:10.1007/s11069-017-2985-1.

John Boakye-Danquah jmb357@mail.usask.ca

1 Department of Geography and Resource Development, University of Ghana, Legon, Ghana

2 School of Environment and Sustainability, University of Saskatchewan, Saskatoon, Canada 